\title{
MUTUAL: \\ KOREOGRAFI YANG TERINSPIRASI DARI PERUBAHAN SOSIAL SUATU PERKAMPUNGAN
}

\author{
Putri Lestari; Setyastuti; Y. Subowo \\ Jurusan tari, Fakultas Seni Pertunjukan, Institut Seni Indonesia Yogyakarta \\ email: lestarip896@gmail.com; utisetyastuti@gmail.com;yohbegog@yahoo.co.id
}

\begin{abstract}
RINGKASAN
Karya tari berjudul "Mutual" ini digarap dalam bentuk koreografi kelompok, ditarikan oleh satu penari putra dan dua penari putri. "Mutual" berasal dari kata mutualisme yang merupakan salah satu bentuk simbiosis dan mempunyai arti hubungan saling menguntungkan. Karya ini berlandaskan pada perubahan sosial yang terjadi di kampung halaman penata. Perkampungan yang dulu dinilai sebagai lingkungan yang kurang baik karena banyaknya permasalahan yang terjadi, kini sudah menjadi lebih baik seiring berjalannya waktu dan adanya imigrasi. Terjadinya imigrasi memisahkan karakter dan suasana antara perumahan dan perkampungan. Meski terdapat perbedaan gaya hidup namun tetap menjunjung tinggi rasa kebersamaan. Suasana dalam perkampungan ini yang menjadi acuan penata dalam proses kreatif penciptaan tari. Karya ini menggunakan bahasa simbol yang diharapkan mampu menyampaikan maksud dan pesan yang terkandung didalamnya kepada penonton, sehingga karya ini tidak hanya menjadi tontonan atau hiburan semata melainkan mampu menginspirasi dan juga sebagai sarana refleksi bagaimana harus bersikap di lingkungan sosial. Dalam hidup bersosialisasi kita membutuhkan bantuan orang lain ataupun sebaliknya, sehingga kebersamaan dan keseimbangan dapat terwujud.
\end{abstract}

Kata kunci : Imigran, Pribumi, Kebersamaan 
JOGED: Jurnal Seni Tari

p-ISSN 1858-3989 | e-ISSN 2655-3171
MUTUAL: KOREOGRAFI YANG TERINSPIRASI DARI PERUBAHAN SOSIAL SUATU PERKAMPUNGAN

\begin{abstract}
The dance work entitled "Mutual" is composed in the form of group choreography, danced by one male dancer and two female dancers. "Mutual" comes from the word mutualism which is a form of symbiosis and means a mutually beneficial relationship. This work is based on the social changes that have occurred in the choreographer's hometown. The settlement that used to be rated as an unfavorable environment due to many issues that occurred, is now getting better over time but also because of the immigration. Immigration separates the characters and the atmosphere between housing and settlement. Even though there are differences in lifestyle, they still uphold a sense of togetherness. The atmosphere in this settlement is the reference for the choreographer in the creative process of dance.This work uses symbolic language which is expected to be able to convey the meaning and the message to the audience, so that this work is not only as a performance or an entertainment, but it is able to inspire and also as a means of reflection on how to behave in a social environment. In social life we need the support of other people and vice versa, so that the solidarity and the balance can be materialized.
\end{abstract}

Keywords: Immigrants, Natives, Togetherness 


\section{PENDAHULUAN}

Kota Pekalongan merupakan kota kecil yang berada di Provinsi Jawa Tengah, salah satu daerah yang dilalui jalur pantura, terdapat banyak sungai, dan merupakan daerah pesisir yang membuat pemukiman penduduk berupa perkampungan dengan pola pemukiman memanjang mengikuti garis jalan, sungai, dan pantai. Karakter masyarakat Pekalongan adalah masyarakat yang spontan, terus terang, dan temperamental, hal ini dikatakan oleh Nuryanto dalam buku yang berjulul Kerusuhan di Pekalongan Jawa Tengah. Dari karakter masyarakatnya menimbulkan gejolak sosial yang terjadi di Kelurahan Kuripan Lor, Gang 4 Kecamatan Pekalongan Selatan Kota pekalongan, di mana daerah tersebut merupakan kampung halaman dari penata. Dahulunya kampung ini adalah kampung yang luas dengan penduduk yang sedikit, banyak daerah kosong dan sepi yang sering dijadikan tempat mabuk ataupun judi. Daerah tersebut merupakan kampung yang dinilai kurang baik, di mana perilaku warganya yang sering beradu dan menyelesaikan masalah dengan cara yang kasar, masih menggunakan sistem melabrak atau mendatangi rumah yang bersangkutan dengan membentak-bentak, terdapat juga beberapa warga yang suka mencuri mulai dari hewan ternak ataupun barang-barang lainnya, juga pemuda yang sering mabuk dan mengamuk, juga warga yang mendidik anaknya dengan keras, hingga kemudian hal ini menyebar ke kampung lainnya dan membuat kampung Gang 4 mendapat julukan kampung maksiat.

Adanya pandangan atau penilaian yang buruk terhadap kampung ini berakibat pada acara 17 Agustusan, yang di mana acara ini merupakan perayaan kemerdekaan Indonesia dan juga sebagai wadah untuk bersilahturahmi dan mempererat kebersamaan. Acara ini dibuat secara bergantian dari satu kampung ke kampung lainnya, setelah giliran dari kampung ini untuk menyelenggarakan acara warga dari kampung lainnya tidak mengapresiasi acara tersebut. Setelah terjadinya pergesekan tersebut, pada tahun 2012 sempat tidak diadakan acara seperti sebelumnya, tidak diadakannya kegiatankegiatan kampung ini berlangsung selama kurang lebih dua tahun. Antusias warga menurun terhadap kegiatan yang diadakan. Dalam artikel yang berjudul Manusia Sebagai Makhluk Sosial, Ratna Puspitasari (2017) mengatakan :

Manusia sebagai makhluk sosial artinya manusia membutuhkan orang lain dan lingkungan sosialnya sebagai sarana untuk bersosialisasi. Bersosialisasi disini berarti membutuhkan lingkungan sosial sebagai salah satu habitatnya maksudnya tiap manusia saling membutuhkan satu sama lainnya untuk bersosialisasi dan berinteraksi. Manusia pun berlaku sebagai makhluk 
sosial yang saling berhubungan dan keterkaitannya dengan lingkungan dan tempat tinggalnya.Manusia bertindak sosial dengan cara memanfaatkan alam dan lingkungan untuk menyempurnakan serta meningkatkan kesejahteraan hidupnya demi kelangsungan hidup sejenisnya. Namun potensi yang ada dalam diri manusia itu hanya mungkin berkembang bila ia hidup dan belajar di tengah-tengah manusia. Untuk bisa berjalan saja manusia harus belajar dari manusia lainnya.

Banyaknya pertambahan warga pendatang di kampung ini membawa pengaruh positif terhadap perkampungan ini, dengan berjalannya waktu kemudian interaksi terjalin dan mulai saling mengenal, dengan gaya hidup yang berbeda kemudian saling belajar, bagaimana warga mencontoh tata perilaku sosial dari warga pendatang, dan warga perumahan ini kemudian dianggap berwibawa sehingga secara perlahan menghilangkan sifat karakter dari warga perkampungan sebelumnya. Seiring berjalannya waktu perilaku kurang baik yang dilakukan beberapa oknum telah memudar, dikarenakan faktor usia, ada yang sudah tertangkap polisi, dan juga yang meninggal, sehingga berkurangnya oknum yang meresahkan.

Acara kegiatan perkampungan kembali dijalankan oleh pemuda-pemudi kampung, merangkul para warga baik perkampungan maupun perumahan untuk bergotong royong dan menjalankan kegiatan bersama. Pada acara tujuh belasan tahun ini (2019) lebih meriah dari sebelumnya dengan penyediaan panggung untuk dangdutan dan jalan sehat (wawancara dengan Abdul Basir, 53 tahun). Pada kegiatan ini tercermin bentuk gotong royong dari warganya saat membersihkan lahan yang akan digunakan untuk area panggung, kebersaman juga tercermin saat para warga jalan sehat dan berada di depan panggung untuk menantikan hadiah undian atau hanya menjadi pasukan goyang dangdut. Berdasarkan cerita tersebut penata menangkap adanya sebuah bentuk kerjasama.

Dalam cerita di atas penata mendapatkan penilaian tentang bagaimana pengaruh warga pendatang terhadap warga asli daerah tersebut, yang mampu menghilangkan kebiasaan buruk dan citra negatif dari kampung tersebut. Dalam hal ini penata membaca kembali dampak yang telah dihasilkan dari kerjasama masyarakat tersebut. Pada hakikatnya manusia adalah makhluk sosial yang membutuhkan dan dibutuhkan orang lain dalam kehidupan. Dengan dibutuhkan dan membutuhkan orang lain tersebut akan menimbulkan suatu bentuk kerjasama pada kehidupan bermasyarakat, dalam kehidupan bermasyarakat rasa kebersamaan dan gotong royong sangat dijunjung tinggi. Apabila masyarakat dalam perkampungan dapat melakukan kerjasama dengan maka akan tercipta lingkungan yang saling memberi keuntungan, kesepakatan yang 
MUTUAL: KOREOGRAFI YANG TERINSPIRASI

DARI PERUBAHAN SOSIAL SUATU PERKAMPUNGAN

terjalin untuk kepentingan bersama, dan kenyamanan.

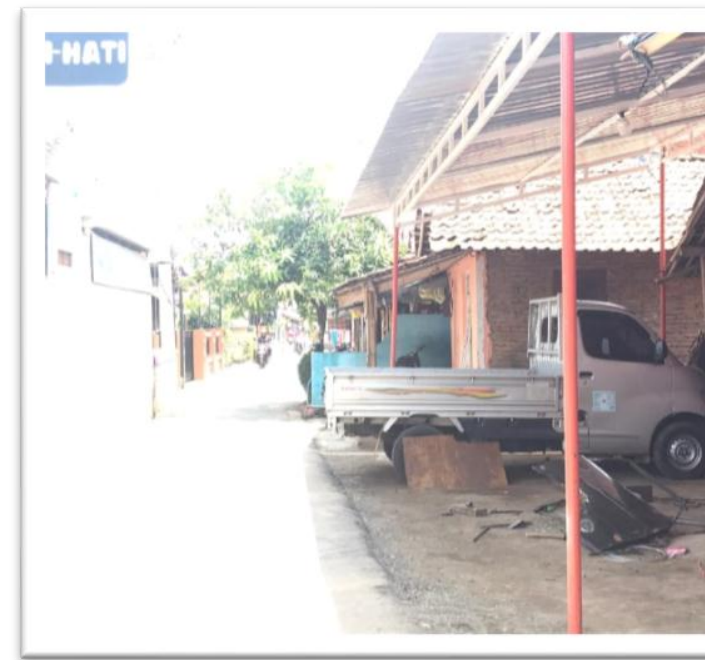

Gambar 1: kondisi lingkungan warga lokal ( dok. Putri, 2019)

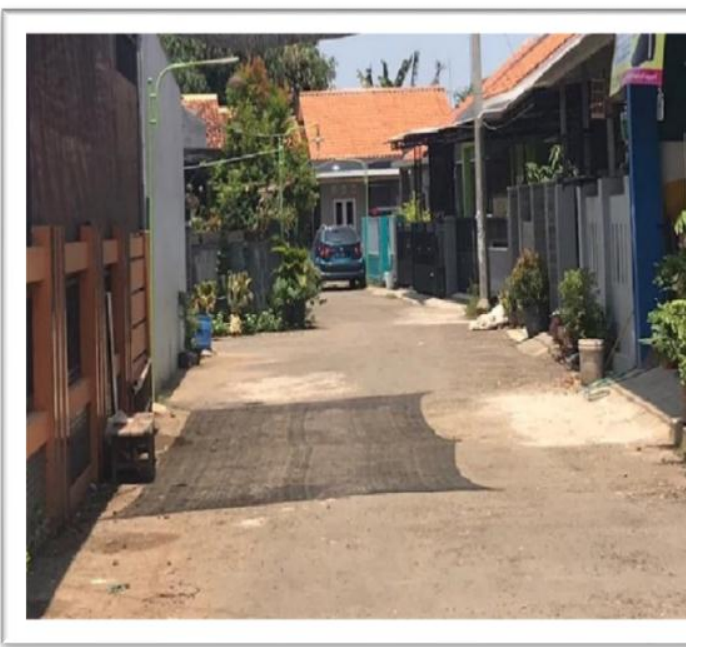

Gambar 2: kondisi lingkungan warga pendatang ( dok. Putri, 2019)

Objek dalam penelitian karya tari ini merupakan bagaimana proses urbanisasi yang terjadi di perkampungan ini. Dari proses urbanisasi ini adanya saling mempengaruhi antar warga. Perubahan karakter dari warga pribumi yang awalnya keras dan banyak
JOGED: Jurnal Seni Tari p-ISSN 1858-3989 | e-ISSN 2655-3171

melakukan hal yang kurang baik kini menjadi berkurang, karena melihat betapa berkelasnya gaya hidup di lingkungan perumahan. Perumahan identik dengan kesunyian lingkungannya dan melakukan interaksi seperlunya, perkampungan identik dengan keramaian dan lebih banyak melakukan interaksi, hal ini kemudian saling mempengaruhi antara imigran dan pribumi. Imigran terpengaruhi oleh pribumi yang sering mengajak interaksi dan pribumi terpengaruhi oleh toleransi yang diterapkan oleh imigran, sehingga dapat membaurnya antara perumahan dan perkampungan. Kebersamaan ini ditandai dari acara-acara kampung yang diselenggarakan untuk kepentingan bersama, kebersamaan ini dapat dilihat bagaimana kerjasama antar warga untuk mengadakan kegiatan dalam rangka memeriahkan ulang tahun Kemerdekaan Indonesia, acara ini sebagai penanda karena merupakan peringatan yang paling meriah dan dinantikan setelah Hari Raya.

Dalam peringatan ulang tahun Kemerdekaan RI yang biasa disebut Agustusan semua warga harus bekerja sama untuk menyajikan panggung hiburan mulai dari iuran, partisipasi masing-masing warga untuk menyediakan jajan (makanan) dan membuka rumah bagi para pengunjung, dan partisipasi mengikuti setiap rangkaian acara, dengan adanya banyak warga maka akan 
semakin meriah. Jadi imigran dan pribumi menyatu dalam acara tersebut oleh ajakan warga pribumi kepada imigran karena sudah menjadi bagian dari warga Kuripan Lor gang 4. Bahkan dimasa sekarang karena banyaknya warga kampung tersebut dibagi menjadi dua RT namun masih menjadi satu kampung. Permasalahan masing sering terjadi namun dalam batas wajar, biasanya permasalah dimulai dari karakter warga pribumi yang mudah marah, sehingga karakter pribumi ini merupakan permasalahan yang diungkap penata dalam karya Mutual. Penyelesaian masalah ini dilakukan dengan adanya kegiatan warga yang akan lebih mempererat ikatan kebersamaa. Warga yang disatukan dalam suatu kegiatan meskipun bermusuhan atau banyak selisih paham maka akan kembali baik karena mengingat dalam satu tujuan yang sama dan kepentingan bersama.

\section{PEMBAHASAN}

Koreografi ini akan mencoba membawa penonton dalam ingatan maupun pengalaman hidup di lingkungan sosial. pada karya ini diberi judul "Mutual" yang berasal dari kata sifat yaitu "Mutualisme" yang mempunyai arti saling menguntungkan, dan mutual sendiri mempunyai kata saling, bermaksud mempresentasikan saling menguntungkan, ketergantungan pada orang lain, dan pengaruh positif dari lingkungan terhadap pribadi seseorang. Karya ini mempresentasikan keegoisan warga pribumi yang dulu dan keindividuan mereka, keuntungan dari keseimbangan masyarakat yang terjadi dengan timbal balik dari tubuh satu dengan tubuh yang lain, bagaimana kesepakan yang terjadi antar penari, dan juga bagaimana tubuh ini merasakan kenyamanan, dengan adanya hal positif yang terjadi di lingkungan masyarakat di daerah tersebut. Tujuan membuat koreografi ini untuk menjadikan kita sadar dan peka terhadap lingkungan sosial di sekitar kita, melatih tubuh kita dalam berperilaku dalam tatanan sosial. Adapun manfaat dari penelitian ini mengetahui perkembangan lingkungan sosial, perubahan dan kemajuan yang sudah dialami.

Dalam realisasi karya untuk memberi kesan pertambahan warga dibantu dengan penggunaan setting siklorama, siklorama berfungsi untuk mewujudkan bayangan penari yang disorot lampu dari arah depan dan samping. Visual yang ditampilkan akan menambah banyak penari dengan gerak yang sinkron. Hal ini merupakan presentasi dari pertambahan warga yang tidak hanya menambah ramai, tetapi juga mempererat kebersamaan, kekompakan dan solidaritas warga. 
MUTUAL: KOREOGRAFI YANG TERINSPIRASI

DARI PERUBAHAN SOSIAL SUATU PERKAMPUNGAN

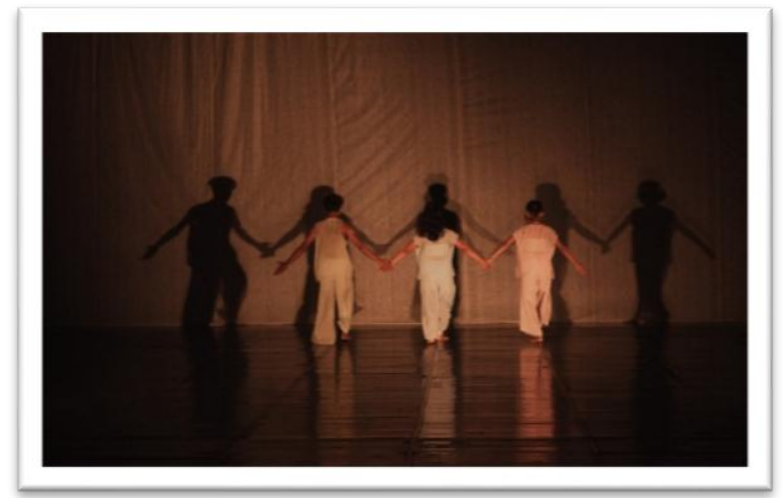

Gambar 3 : simbol dari bayangan penari sebagai representasi pertambahan warga ( dok. Bagus, 2020 )

Karya ini merupakan sebuah harapan untuk setiap individu dapat saling toleransi, saling membantu, dan saling mengasihi satu sama lain sebagai makhluk sosial. Setiap individu perlu merefleksikan dirinya agar melihat apa yang telah diperbuat dan bagaimana dampak bagi sekelilingnya. Dalam lingkunga sosial apa yang kita tanam maka itu yang kita tuai.

Referensi karya didapat ketika merasakan langsung suasana perkampungan tersebut, juga hasil dari diskusi bersama narasumber. Berdasarkan hasil wawancara yang mendukung atas pemikiran, sehingga menjadikan objek perkampungan sebagai dasar penciptaan koreografi Mutual. Referensi lainnya berdasarkan pengalaman dalam aktifitas sehari-hari di perkampungan.

Karya tari Mutual merupakan refleksi diri terhadap pengalaman hidup selama tinggal di lingkup perkampungan tersebut. Penata mengalami sedikit demi sedikit rasa yang
JOGED: Jurnal Seni Tari p-ISSN 1858-3989 | e-ISSN 2655-3171

nyaman dan dapat mengekspresikan ketika bertemu dengan orang lain. Sebelumnya penata lebih kepada invidu yang tertutup dan merasa kurang nyaman ketika melakukan interaksi, hal ini dikarenakan adanya rasa takut melakukan hal yang salah mengingat banyak warga yang sensitif. Rasa kenyamanan berekspresi mulai muncul dan lebih terbuka pada setiap orang bahkan warga yang baru pindahan.

Karya tari Mutual ditampilkan dalam format video dengan durasi 16 menit, dengan pembagian adegan yang terstruktur. Adegan dalam karya ini dipisahkan berdasarkan esensi dan nilai yang disampaikan. Pembagian struktur karya terdapat 4 bagian, yaitu:

\section{Kedatangan (Adegan 1)}

Pada bagian ini menggambarkan kedatangan warga pindahan ke kampung tersebut, dengan menggunakan gerak melambaikan tangan, gesture tubuh permisi di Jawa, dan uluran jabat tangan, dikarenakan gerak tersebut merupakan gesture spontan tubuh yang akan dilakukan jika bertemu dengan orang lain, terlebih lagi jika bertemu dengan orang yang belum dikenal yang masih merasa kaku. Menggunakan gerak repetisi untuk mempresentasikan banyaknya imigran yang datang secara terus menerus, hingga membuat kampung Kuripan gang 4 sekarang padat penduduk. 
JOGED: Jurnal Seni Tari

p-ISSN 1858-3989 | e-ISSN 2655-3171

Terdapat 3 penari di apron dengan melakukan motif gerak tegur sapa, hal ini mempunyai maksud untuk memberikan sensasi bertegur sapa dengan penonton di karya ini apabila dapat dipertunjukkan. Penata menganggap seperti adanya 2 wilayah yang berbeda antara penari dan penonton, di sisi lain menjadi penonton dan di sisi lain menjadi yang ditonton, sama halnya dengan 2 bentuk pemukiman yang berbeda pada satu wilayah. Dan pada bagian ini merupakan salah satu simbol sebuah pertemuan dan harapan agar dapat terjalinnya kerja sama yang baik.

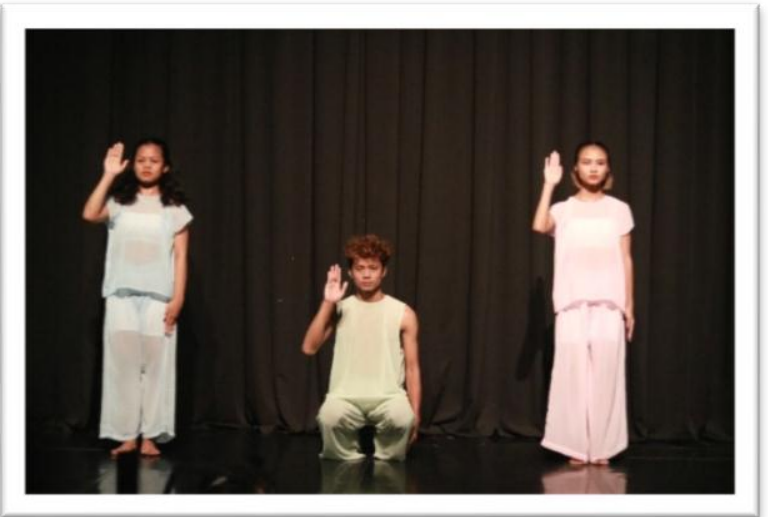

Gambar 4 : sikap gerak menyapa dalam motif gerak Tegur Sapa ( dok. Asad 2020 )

2. Pengaruh yang dibawa oleh imigran, atau karakter imigran (Adegan 2)

Pada bagian ini dieksppresikan sifat dari karakter imigran, yang lebih tenang dan berwibawa, dan saling toleransi dan membantu satu sama lain dan lebih kompak, meskipun baru mengenal satu sama lain tetapi
MUTUAL: KOREOGRAFI YANG TERINSPIRASI DARI PERUBAHAN SOSIAL SUATU PERKAMPUNGAN

mereka mampu hidup berdampingan dengan damai. Tidak banyak permasalahan, dan juga keadaan rumah dan ekonomi dari kelas atas dan orang-orang yang berpendidikan. Maka karakter dari imigran ini sangat berbanding terbalik dengan pribumi kampung tersebut.

Pada bagian ini gerak yang digunakan lebih kepada gerak yang tenang dan mengatur keseimbanga antara 3 penari, dengan gerak berpegangan tangan dan penari bagian tengah menjadi pusatnya dan juga sebagai tumpuan untuk menahan dua beban agar seimbang dan lebih ringan, dilakukan dengan tempo lambat untuk mencapai ketenangan yang diinginkan. Pada bagian ini juga mengekspresikan kebersamaan warga perumahan dan kekompakan mereka dalam mengadakan kegiatan. Pada motif bertumpu merupakan gambaran dari imigran yang lebih tenang dan berwibawa, dan juga merupakan simbol dari kita sebagai makhluk sosial tidak dapat bertahan tanpa adanya bantuan dari orang lain.

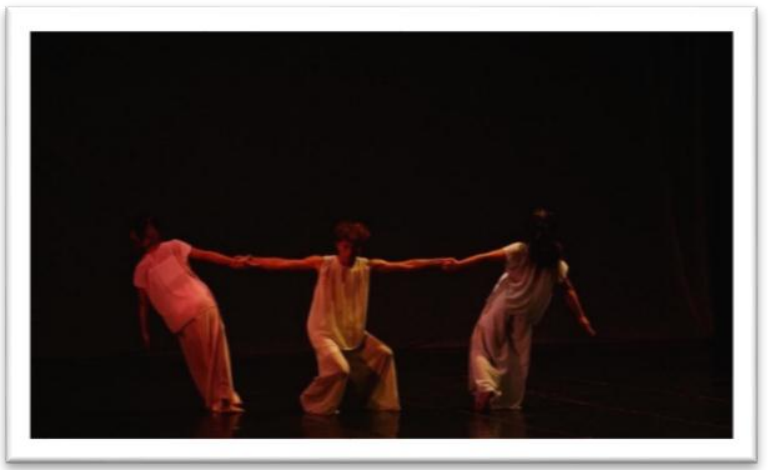

Gambar 5 : sikap bergandengan dengan tumpuan penari tengah ( dok. Bagus, 2020 ) 
MUTUAL: KOREOGRAFI YANG TERINSPIRASI

DARI PERUBAHAN SOSIAL SUATU PERKAMPUNGAN

Motif gerak bertubi dibuat dengan hitungan yang bertambah, dengan perhitungan merupakan satu gerak, sehingga hitungannya menjadi 1 2, 123,123 4, dan seterusnya hingga mencapai hitungan 8 . Gerak ini merupakan gerak yang terinspirasi dari bagaimana ungkapan tubuh senang dan gembira. Gerak ini juga merupakan dari ekspresi pertambahan warga yang terjadi di kampung Kuripan.

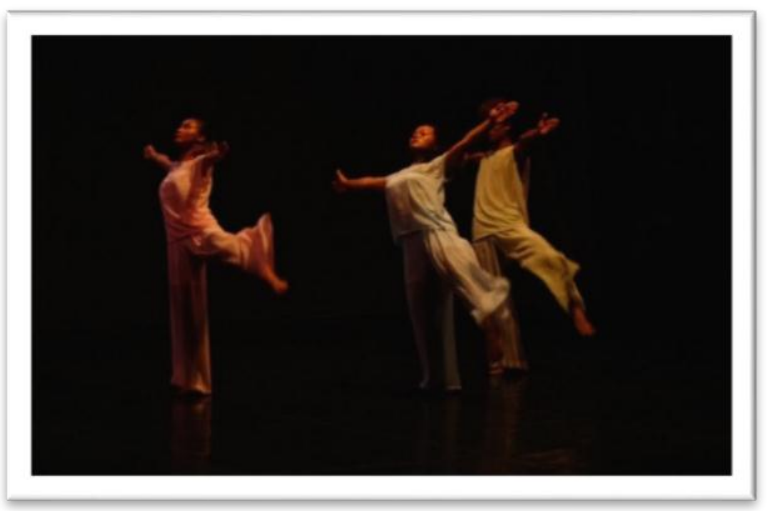

Gambar 6 : sikap merentangkan tangan pada motif bertubi

( dok. Bagus, 2020)

3. Keegoisan, karakter dari pribumi (Adegan 3)

Pada bagian ini penata ingin mengekspresikan bagaimana karakter pribumi di masa dulunya, sebelum adanya pertambahan penduduk. Pada bagian ini gerak yang digunakan hanya satu motif yaitu dorongan antar punggung, gerak ini dilakukan dengan tiga penari saling memunggungi dan saling mendorong satu sama lain untuk dapat saling mengalahkan.
JOGED: Jurnal Seni Tari p-ISSN 1858-3989 | e-ISSN 2655-3171

Gerak mendorong ini mengekspresikan sifat dari pribumi yang selalu ingin menang sendiri, dan sangat sensitif. Tetapi di balik gerak yang saling mendorong ini terdapat keseimbangan di antara 3 penarinya, pada awal memulai jika penari tidak saling bentumpu pada punggung penari lain maka lingkaran tersebut tidak kokoh, seperti halnya dari pribumi ini yang meskipun sering berselisih tetapi mereka tetap sejalan, karena perselisihan ini lebih kepada individu pribadi.

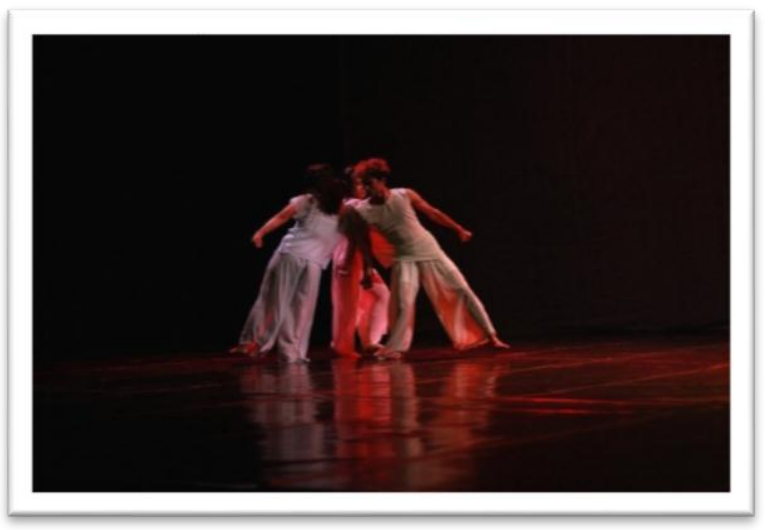

Gambar 7 : sikap adu bahu sebagai representasi perselisihan ( dok. Asad, 2020 ) 
JOGED: Jurnal Seni Tari

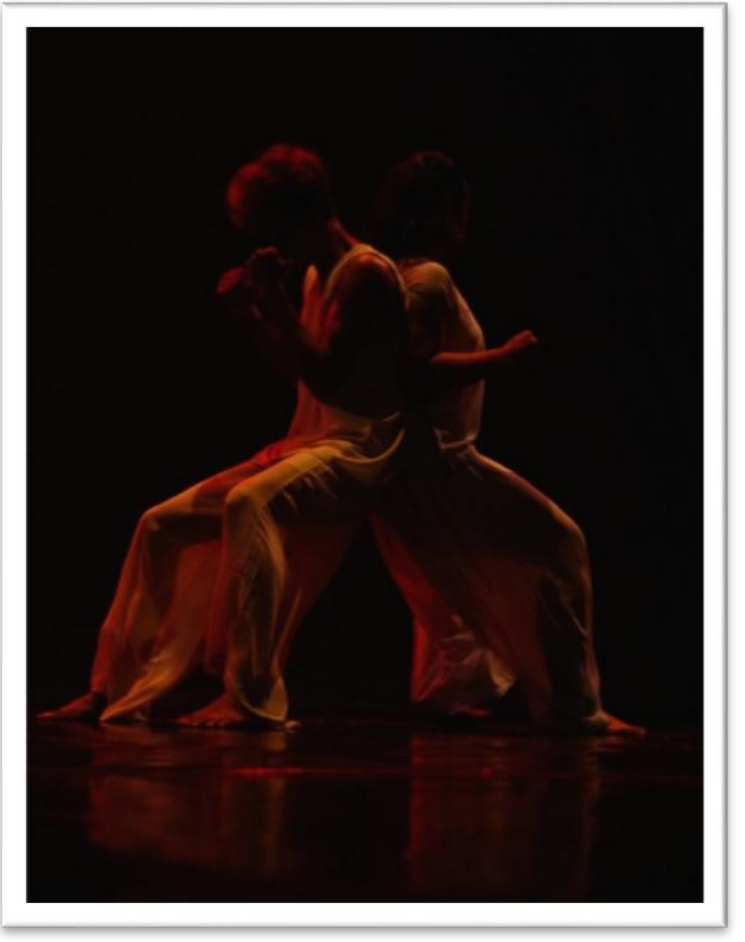

Gambar 8 : sikap adu punggung sebagai representasi perselisihan

( dok. Asad, 2020)

Pada gerak ini satu persatu penari kalah karena terdorong dan hanya menyisakan satu penari sebagai seorang yang paling merasa benar dan baik. Satu penari kalah dan menyisakan dua penari dengan melakukan ragam gerak yang masih sama dengan sebelumnya. Dari dua penari yang beradu kemudian menyisakan satu penari putra dengan maksud representasi warga pribumi yang beradu dan menyisakan pemenang. Pada motif gerak ini diberi nama motif individu, dengan maksud menggambarkan kemenangan dari pribumi yang telah berselisih dengan menggunakan gerak keras dan ditarikan tunggal oleh penari putra, gerak ini dilakukan melantai dan lebih menggunakan pengalaman
MUTUAL: KOREOGRAFI YANG TERINSPIRASI DARI PERUBAHAN SOSIAL SUATU PERKAMPUNGAN

kolektif dari tubuh penari sehingga memuncul keindividuan dari penari.

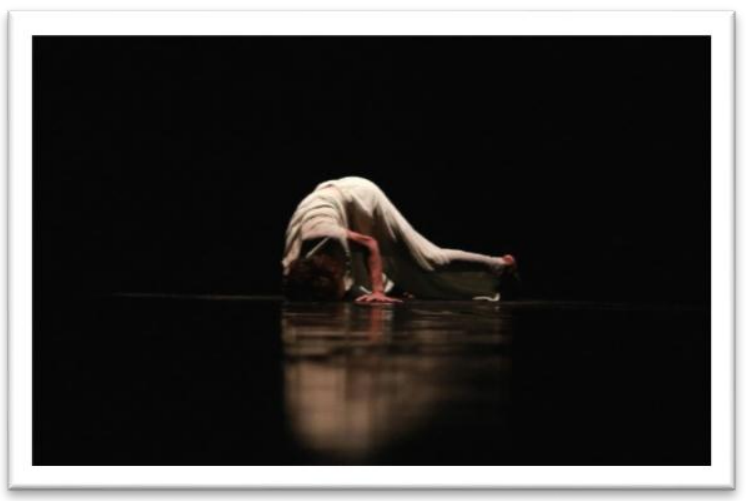

Gambar 9 : penari putra dengan gerak melantai sebagai ekspresi individualis ( dok. Bagus, 2020 )

4. Kebersamaan (Adegan 4)

Pada bagian ini mengekspresikan bagaimana menggebu-gebunya para warga sekarang disetiap kegiatan kampung yang dilaksanakan, begitu kompak dan sangat ramai. Pada bagian terakhir ini dalam menggambarkan kebersamaan, digunakan gerak rampak yang bertempo semakin cepat. Pada bagian ini lebih mempresentasikan bagaimana keadaan kampung yang sekarang, pribumi yang mempunyai karakter kasar akhirnya dapat bergabung menjadi satu dengan imigran atau perumahan. Hingga pada akhirnya sekarang dapat dilihat kebersamaan dua kelompok warga yang berbeda karakter tetapi hidup dalam satu wilayah. 
MUTUAL: KOREOGRAFI YANG TERINSPIRASI

DARI PERUBAHAN SOSIAL SUATU PERKAMPUNGAN

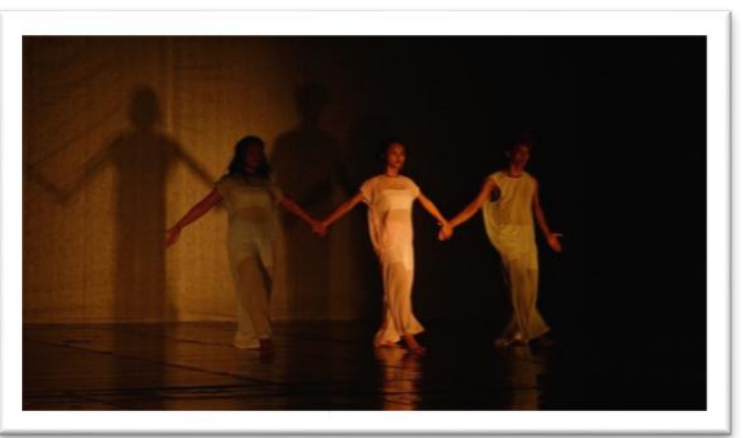

Gambar 10 : penari bergandengan tangan sebagai ekspresi kebersamaan ( dok. Asad, 2020 )

Gerak pada bagian ini dilakukan dengan rampak dan tempo yang semakin cepat, dalam gerak ini menggambarkan kekompakan, semangat, antusias warga di masa sekarang, dalam gerak bergandengan tangan merupakan simbol dari kebersamaan.

\section{PENUTUP}

Karya Mutual adalah karya tari yang terinspirasi dari pengamatan terhadap lingkungan sosial tempat tinggal penata di daerah Kota Pekalongan. "Mutual" yang berasal dari kata "mutualisme" yang mempunyai arti hubungan timbal-balik yang saling menguntungkan antara dua pihak. Dalam karya ini akan menggambarkan pengaruh dari imigran terhadap pribumi Kuripan Lor gg 4, dengan melihat apa saja perubahan yang terjadi sebelum ada pertambahan warga dan sekarang sudah banyak warga dan merupakan kampung padat penduduk. Menggambarkan bagaimana pengaruh positif banyaknya warga pindahan,
JOGED: Jurnal Seni Tari p-ISSN 1858-3989 | e-ISSN 2655-3171

mempresentasikan kampung yang dulu dan kekurangannya, serta di masa sekarang yang kerjasama warga sudah dapat terjalin dengan baik.

Karya ini diciptakan dengan beberapa tujuan yakni untuk membuat kita sadar dan peka terhadap lingkungan sosial di sekitar kita, menyadari tubuh kita dalam berperilaku dalam tatanan sosial. Membuat koreografi dengan sumber fenomena sosial yang menggambarkan lingkungan sosial yang mampu bekerjasama dengan baik. Mengungkapkan pengalaman dalam hidup di perkampungan yang mempunyai banyak konflik. Menyadari dinamika sosial yang terjadi, dan pengaruh lingkungan terhadap diri kita. Dan juga merupakan ungkapan emosi yang selama ini tinggal dalam lingkungaan tersebut yang menimbulkan adanya rasa ketidaknyaman. Banyak hal yang tidak dapat sampaikan secara langsung tetapi dapat ditumpahkan dalam karya Mutual ini. 
JOGED: Jurnal Seni Tari

p-ISSN 1858-3989 | e-ISSN 2655-3171

\section{DAFTAR SUMBER ACUAN}

Ellfeldt, Louis. 1988. A Primer for Coreographers. USA : Waveland Pr.Inc.

Terjemahan Sal Murgiyanto. 1997. Pedoman Dasar Penata Tari.Jakarta : Lembaga Pendidikan Kesenian Jakarta.

Dana, I Wayan. 2016. Melacak Multikulturalisme Di Indonesia Melalui Media.

Rajutan Kesenian . Yogyakarta: Cipta

Danesi, Marcel. 2010. Pesan, Tanda, makna.

Yogyakarta: Jalasutra

Dibia, I Wayan dkk. 2006. Tari Komunal, Jakarta : Kantor Sekretariat Lembaga Pendidikan Seni Nusantara.

Hadi, Y. Sumandiyo. 2003. .Aspek-Aspek Dasar Koreografi Kelompok, Yogyakarta: Elkapi.

Hadi, Y. Sumandiyo. 2016. Koreografi: Bentuk - Teknik - Isi, Yogyakarta: Cipta Media (edisi Revisi).

Hadi, Y. Sumandiyo. 2017. Koreografi Ruang Prosenium, Yogyakarta: Cipta

Media (Cetak Pertama).

Hawkins, alma M, 1964.Creating Through

Dance, New Jersey: Princeton Book Company.

Jung, Carl G. 2018. Manusia Dan SimbolSimbol, Simbolisme Dalam Agaman, Mimpi Dan Mitos. Yogyakarta :

\section{BASABASI.}

Langer, Suzanne K. 2006. Problematika Seni.

Bandung : Sunan Ambu Press.
MUTUAL: KOREOGRAFI YANG TERINSPIRASI DARI PERUBAHAN SOSIAL SUATU PERKAMPUNGAN

Lubis, Mochtar. 2016. Manusia Indonesia. Jakarta : Yayasan Pustaka Obor Indonesia. (cetak kelima)

Martono, Hendro. 2012. Ruang Pertunjukan dan Berkesenian. Yogyakarta: Cipta Media

Martono, Hendro. 2015. Mengenal Tata cahaya Seni Pertunjukan. Yogyakarta: Cipta Media

Murgiyanto, Sal. 2002. Kritik Tari, Bekal dan Kemampuan Dasar. Bandung :

Masyarakat Seni Pertunjukan Indonesia.

Martiara, Rina dan Budi Astuti. 2018. Analisis Struktural Sebuah Metode penelitian Tari. Yogyakarta: Badan Penerbit ISI Yogyakarta.

Raditya, Ardhie. 2014. Sosiologi tubuh membentang Teori diranah aplikasi.

Yogyakarta: Kaukaba dipantara.

Riyanto, Armada. 2018. Relasionalitas, Filsafat Fondasi Interpretasi : Aku, Teks, Kanisius. Liyan, Fenomen.Yogyakarta : PT

Soyomukti, Nurani. 2016. Pengantar Sosiologi, Dasar Analisi, Teori, Dan Pendekatan Menuju Analisi MasalahMasalah Sosial, Perubahan Sosial, Dan Kajian-Kajian Strategis. Yogyakarta : AR-RUZZ MEDIA. (cetak keempat)

Soedarsono. 2006. Trilogi Seni Penciptaan, Eksistensi, Kegunaan Seni. Yogyakarta : BP ISI Yogyakarta.

Smith, Jacqueline M. 1985. Dance Composition: A Practical Guide of Teacher, London: A \& Black.

Sumardjo, Jakob. 2006. Estetika Paradoks. STSI Bandung: Sunan Abu Press.

Sumaryono. Antropologi Tari, 2011. Media Kreatif, Yogyakarta. 
MUTUAL: KOREOGRAFI YANG TERINSPIRASI

DARI PERUBAHAN SOSIAL SUATU PERKAMPUNGAN
JOGED: Jurnal Seni Tari p-ISSN 1858-3989 | e-ISSN 2655-3171

Suyanto, Bagong dan Sutinah. 2005. Metode

Penelitian Sosial Berbagai Alternatif

Pendekatan. Jakarta : Kencana

Prenadamedia Group

Synnott, Anthony. 2003. tubuh sosial simbolisme, diri, dan masyarakat,

Yogyakarta: JALASUTRA.

Triratnawati, Atik. 2012. Revitalisasi

Kesenian Sintren di Kota dan Kabupaten

Pekalongan, Yogyakarta : Balai

Pelestarian Nilai Budaya. 
